\title{
Development of China's educational policy in the new context of the management system
}

\author{
Xinqiang GAN \\ Zaozhuang Vocational College of Science \& Technology \\ Tengzhou, 277500 China
}

\begin{abstract}
Currently, the reform of state administration is the paramount factor in policy adjustments of the education management system actuation. "Education Plan" makes a clear direction for deepening reform of education management. The local educational development put forward new requirements on the current education management system. Under the new situation, the realistic question in education management system which exists in the policy process is the direct cause of policy adjustments. In order to implement policy adjustments, authorities need to grasp the scale, elaborately demonstration, clear thinking respecting the law on the basis of the policy process. Planning the specific measures in adjusting the system of education management policy requires departments to grasp the focus, aiming highlight to the issue, laying stress on enriching and perfecting the unified leadership of the central and provincial governments to ordinate local education management systems who are responsible for grading policy system.
\end{abstract}

Keywords- new background; education management system; policy development

\section{INTRODUCTION}

Since the reform of state administration promoted adjustment policies in some field of education, China has implemented five reform of the administrative system. Party Congress established the main goal- "establishing a relatively complete administrative system with Chinese characteristics up to 2020," to speed up the pace of reform of the administrative requirements. The next round of administrative reform is relying on large departments, the reconstruction of government power structure and organization system .All above can promote the formation of a dynamic, highly efficient, more open management system which is helpful for scientific development. Large institutional sector is an important trend in the future administrative reform. Exploring the implementation of the functions in the organic unity of the country's largest sector reform .It can reduce the number of initial implementation department, streamline goals, resolve overlap, cross, conflict problem between departmental responsibilities, authority, and other issues in certain degree, and change long administrative situation. Importantly, the reform of the central institution can make a radiation and leading role for the local produce in a considerable degree. The local government sector zealously reform the large department system through structural reform of government departments, which is definitely explore the reconstruction of the government power structure and organization system, perform its functions and modes fully and properly. Administrative system as an important part of political reform, certainly greatly promote education management reform process. Education management system policy is part of the national education policy, which provides management and arrangements on educational institutions as an integral part of the national administrative system content. The adjustment of education management system policy is the general requirement in building socialism with Chinese characteristics under the administrative system of our education management system to optimize the integration of relevant policies. The reform of national administrative system is not only the premise and basis of the education management system policy development, but also the maximum actuation policy adjustment factor. "Education Plan" for education management system indicate the direction that "Education Plan" is to guide the development of China's education reform programmatic document ,which reflects the basic principles of education reform and innovation to promote scientific development, to speed up the reform of key areas and key links pace, including the management system of education reforms .It plan the overall design, put forward the goal of education management system from the macro, tasks and key reform that requires deepening education management system and improving public education services. The reform of education management system should be further "decentralization" of the key tasks which means further decentralization to local government and further decentralization to the school.

\section{EDUCATION POLICY}

Education management policy is "principles and policies related to the development of education in the government or political parties, which is the main task and the general principle of the state or a political party in a certain historical period, embodied in the general policy in the field of education." "Education policy is the operative norm stipulated by organizations and teams who bear legal or educational responsibility in order to achieve educational goals and tasks in a certain period and provisions. "" Education policy is a code of conduct for the realization of a political party or state educational mission and developed in a certain period. "" Education policy is a purposeful, organized dynamic development process, based on the 
actions of political parties and the government and other political entities criteria in a certain historical period .It coordinate educational internal and external relationships to achieve certain educational goals and tasks. "" Education executive education policy for the needs of society and the future development of current trends, developing policy and programs through legislation or executive under the order of the legalization procedures to be performed as a criterion for educational institutions. "" Education policy is related with some kind of attitude statements which usually recorded on the policy document." It can be defined as" will or should follow the specific issues related to educational principles and actions to achieve the expected goals. "" Education policy is the guide line which is for achieving national and political education administrative goals. "" Education policy is political measures on education, a concrete manifestation of the rights and interests related to education. "Education policy should be" a normative provision made by nations for the completion of certain tasks, achieving educational goals, and coordination of education after making a strategic internal and external relations, "" Education policy is for achieving development and implementation of management education in the process of to determine and adjust the relationship between education interests in a specific period of education, which made by organizations and groups who bear legal or administrative responsibility. Generally speaking, education policy come from the areas of public policy. "In the sense of logic, among policy, public policy and education policy is the concept of the relationship between higher concept and lower concept .It is meaning to that the concept of public policy is to lower the concept of policy and education policy is to lower the concept of public policy. "In other words, education policy has the basic characteristics of policy and public policy. With the rise of the modern state and the development of modern education, education has increasingly public features and characters. Education activities have increasingly public nature. Education field is more and more like a public field .Education increasingly become a public issue. Education study and methodology increasingly become a public issue which reflect the complex nature of thinking, increasing the need for public education theory "nourish"; educational practice getting into the torrent of social change.

\section{THE MICRO RESEARCH ON EDUCATION POLICY VALUE}

The micro research on education policy value focus on the education system and educational activities in a miniature view of education policy activities and behavior as a study to analyze and study its value .The study on market value of education policy is basic on education market-oriented policies which to reflect its outlook for the study of the theme. Through carding basic educational market-oriented policies ,discussing the policies inherent contradictions, pointing out the "rational ignorance "of educational administrative departments, causing the product to deviate public basic education characteristics. A series of basic education market reform policies, repeatedly change the background in the absence of any policy debate. That not only affects the value of the position of the various stakeholders and expect for results, but also affects the policy of seriousness and credibility. The value of education policy debate is more important factors over policy issues, situational facts and analysis techniques .For to amendment the deviation of correction policy and to achieve a various of basic education depends on a systematic and political market, the positive interaction of the school's educational policies and the need for value argument. The college entrance examination is a result of individual interests and values of the game demands. The implementation of policies are reflected in the value of certain tendencies, "the value and significance has become an essential element of education policy activities and tend to have a decisive impact on education policy activities. "Therefore, reflecting the changes in the course of new China college entrance examination policy for clarify the policy, as reflected in the values of great significance. Research on the changes of China's new education policy reflected in the value orientation staging that are equal important -political and economic values: First, the start of college entrance examination system (1949 to 1957); including: opening the door to the workers and peasants; Founding political values in the inchoate entrance policy ; all are undone: the beginning of the founding of the economic values entrance policy. Second, the political value of alienation; the repeated and tortuous college enrollment policy (1958 to 1976); which specifically include: "Education Revolution": the repeated of entrance policy and political values; repeal and recommended: the alienation of admissions policies of the political value of colleges' and universities' orientation. Third, the transition from the economic value to the selfvalue: the entrance policy Market Economy (1977-present). These include: restoration and enrollment: fully reflect the economic value of the entrance policy orientation; science and democracy: the entrance of self-value policy values. On the basis of the analysis phase, the study believes that the new entrance policy changes contain a certain value orientation in Chinese history. On the whole, it come from the political value to the economic value, and ultimately return to the overall value orientation around the value of education and human-centered .From now on, the future college entrance examination policy should adhere to the overall self-value as the core values .Its procedure should be more scientific, democratization .Establishing the evaluation institutions and systems of the college entrance examination policy in order to promote the efficient operation of the college entrance examination policy.

\section{EDUCATION MANAGEMENT SYSTEM}

Education management system is a set of institutional mechanisms which works on the management of the organization in the educational aspects .It insures that the whole educational system can run orderly. It includes various agencies within the education system, the terms of reference of the staff within the organization, reporting superior and subordinate relationships and so on. 


\section{EDUCATIONAL ADMINISTRATION SYSTEM}

Taking a panoramic view of the year, the reforms of education management system promote a new development of education in China .But there will be a lot of problems appearing in the process. First, in some places, for the trend and market-driven, they development, enrollment and setting up curriculums. The curriculums isn' $t$ meet the conditions, which is likely to cause the same or similar subjects duplication .It didn' t get corresponding returns while spent money on the curriculum resources. Meanwhile, it resulted in a waste of resources. Some schools do not have the appropriate qualifications, but issued a variety of academic diplomas indiscriminately in violation of the policy, resulting in the presence of some unhealthy trends in society. Second, in recent years due to appear of private schools organized by the increase of social forces .How to coordinate the two main public schools and private schools is becoming a major problem faced by the current management system. At the beginning, the two are in different locations. The central grasp the vast majority of social resources which has an innate sense of superiority, but the social forces of educational resources occupies a small part. The difference between the two has the impact on educational management. Third, the diversity of the subject organized by the school further increases the difficulty of the government's macrocontrol of education which results in a contradiction of talent supply and market demand.

\section{NEW DEVELOPMENTS IN THE FUTURE OF EDUCATION MANAGEMENT SYSTEM}

We can speculate from the following three aspects in the future development of the education management system. First, the central government will continue to manage the educational permissions to local. Local governments and schools will gave more management rights. Management systems are taking changes from top to bottom within the educational system. Under the influence of this change, the local government began to gradually expand administrative rights for local education. Second, the government has unshakable responsibility on school construction .Therefore, education should be incorporated in the regulation of the central government for the advantages of this management system .It is normal for the school system set up to provide a guarantee. But with the development of China's market economy, society needs more and more educational resources .If education solely ruled by the government, it would make increasingly heavy burden on government. Thus, the public advocate starting to rely on social forces to participate in the school and the development of education.
Various school educational forces can make a prominent role. Third, previously resources are under the management of government. The central government's decision-making on its provisions based primarily on education needs .Thus, the supply and demand for education is unanimous. It would make the some people outside the country's policy accept less education provided by the State. With the development of society, the demand for a variety of education are growing especially the education resources besides compulsory education .If it is supplied by previous education, it certainly cannot meet the needs of the community. So there are more forces on the school in society. They began offering rich educational resources to meet the growing educational needs.

\section{CONCLUSIONS}

With the widespread promotion of the concept of education and social development, people will gradually realize that education is throughout individual life. Thus, the education management system has entered a new period of development. The reform of educational management improves their education management system has important theoretical and practical significance. Nowadays, on the one hand,with rapid development of economic and cultural, our education management system faces the influx of foreign educational institutions .On the other hand, while people understand the concept of education .Knowledge update extremely quick triggered by the current demand for knowledge of culture, higher education also facing good opportunities for development.

\section{References}

[1] Liu Ming. Organic combination of traditional and modern education management system [N]. China Education Daily, 2003/08/16.

[2] Liu deposit Retrospect and Prospect of China's reform and opening up higher education management system [J] Fudan Education Forum, Jan. 2009: 43-47 + 57 .

[3] Zhou Chuan Chinese Higher Education Management System Policy Analysis [3] [J] Higher Education Research, 2009,08: 49-54.

[4] Yang Runyong new context of the management system of education policy studies Adjustment [J] Education Research, 2011,03: 26-30.

[5] Chen Jinxiu. Private vocational education management system research [D]. Shandong Normal University, 2014.

[6] Malu Ting Reform in Higher Education 30 years - history, experience and thinking [J] China Higher Education Research, 2008,11: 12-17.

[7] $\mathrm{Hu}$ Jianhua Chinese Higher Education Management System Analysis [J] Nanjing Normal University (Social Sciences), 2005,04: 75-80. 